Original Article

\title{
Legacy of an Anatolian Sufi from a Psychological Perspective: Case of Yunus Emre
}

\author{
Murat Dinçer ${ }^{1}$ \\ POEM Counseling Center
}

\begin{abstract}
The Sufi perspective exhibited by Yunus Emre has provided an ontological comprehension that explains the meaning of existence and life. The origin of "self" or "ego" is based on the Soul that is Truth (Hakk) within this ontological understanding grounded in Oneness. It gives endless meaning to people as it refers to the value of humans not in terms of their individual attributes but their divine side. The only possible way to transition from the illusory formed self to the real self, the Soul, is through the love of Truth and with a mentor or guide that has experienced this love of Truth. The relationship that is established with the mentor or guide heals relational problems and has a nature that also frees humans from their biological, relational, societal, and psychological boundaries. One's moral sentiment based on their perception of life is oriented to purify the negative attributes that sustain the illusory self to gain virtues that will allow one to experience the real self. Yunus has indicated an understanding of existence, meaning of life, and a remedial, liberating model of relating as well as an ethical approach towards humanity in this era of narcissism.
\end{abstract}

Keywords

Yunus Emre • Self • Human • Sufism・Psychology

Psikolojik bir Bakış Açısından Anadolulu bir Sufi'nin Mirası: Yunus Emre Örneği

$\ddot{\mathrm{O} z}$

Yunus Emre'nin ortaya koyduğu tasavvufi anlayış, varlığı ve yaşamı anlamlandıran ontolojik bir bakış açısı sunmaktadır. Tekliğe dayanan bu ontolojik bakışta benliğin aslı bu varlığı meydana getiren asıl Can olan Hakka dayandırılmaktadır. İnsanın değerini kişiselliğine değil tinsel, tümel yönüne bağladığı için insana sonsuz bir değer verir. Aslında bir yanılsama olan benliğinden soyunup bu tümel kişiliğine geçişi ancak hakikat aşkıyla ve bu aşkın yaşandığı mahal olan bir yetiştirici ile mümkün olur. Bu yetiştirici ile kurduğu ilişki hem eski ilişkisel zorlukları sağaltıcıdır hem de bunun ötesinde insanı bağlayan biyolojik, ilişkisel, sosyal ve psikolojik tüm bağlarından özgürleştirici niteliktedir. Onun hayatı algılayışından kaynaklanan ahlak anlayışı ise kişinin aslında bir yanılsama olan benliğini ayakta tutan olumsuz özellikleri arındırmaya ve ona özünü yaşatacak erdemleri kazandırmaya yöneliktir. Bu haliyle narsisisizm çağındaki insana hem bir varlık algısı, hem bir hayat anlamı, hem iyileştirici ve özgürleştirici bir ilişki modeli hem de bir etik anlayışı göstermektedir

Anahtar Kelimeler

Yunus Emre • Benlik • İnsan • Tasavvuf • Psikoloji

1 Correspondence to: Murat Dinçer, Private practice, POEM Counseling Center, Üsküdar, İstanbul 34662 Turkey. Email: muratdncr@gmail.com

Citation: Dinçer, M. (2016). Legacy of an Anatolian sufi from a psychological perspective: Case of Yunus Emre. Spiritual Psychology and Counseling, 1, 27-45. http://dx.doi.org/10.12738/spc.2016.1.0004 
Our world is currently experiencing difficult days with conflicts triggered by ethnic, religious, political, and economic discriminations. During the 13th century when Anatolia had passed through such a chaotic time after the Mongol raids, the most prominent figures of Sufism such as İbn-i Arabi, Mevlana, Sadrettin Konevi, Hacı Bektaşı Veli, and Yunus Emre appeared. After this period, Yunus Emre became common in the language of Anatolian Sufism and has turned into a figure that brings people together from different segments of society. How can a person about whom we are unsure of so many details in his life such as his birth, death, residence, family, order, and education (Halman, 2003) have maintained this effect over centuries just as in his initial days? The answer to this question is probably that he realized the secret of "Truth is hidden in the person" and stated this in its simplest and most focused way.

Considering the Earth, it is obvious that humans are the most superior creature due to their efforts and the extent to which consciousness has been derived from them. In Islamic culture, Adam was the one to whom all angels prostrated, and to kill one human is considered equivalent to killing all of humanity. Humans are so indiscriminately precious that in both all critical parts of the Qur'an and the major speeches of Mohammed Mustafa $_{\text {saws }}$, this most precious creature is addressed as " $\mathrm{O}$ People..." without discriminating between believers and nonbelievers, women and men, young and old, or rich and poor. Yunus Emre was a Sufi who revealed that the secret of Truth is hidden in humans; therefore humans are the most valuable entity as he explained in the simplest of ways. He stated this essential knowledge by saying "Knowledge should entail a full grasp of knowledge: Knowledge means to know yourself, heart and soul." Again, after mentioning religious rituals, he said that the best one is "to love and be loved," thus relating wisdom to the reality of being human. He said "the one who does not see the nations of the world as one nation is a rebel against Truth" and emphasized that real faith is seeing the Truth hidden in each human and loving people without discrimination.

Understanding the wisdom of Yunus Emre has a priceless value because it has such power in saving humanity from all of the ongoing fights and conflicts caused these days by discrimination. This study aims to help this value be understood and disseminated based upon Yunus Emre's works: The Divan and Risaletün Nushiyye.

\section{His Life and Artworks in Brief}

Yunus Emre was a public figure, yet the first academic studies about him only began in the beginning of the 20th century. As a result of these studies, it was assumed but not certain that he was born around 1240 in Sivrihisar, Central Anatolia; other researchers have assumed that he was a Turkmen who later immigrated to Anatolia (Tatc1, 2013). Although there have been several claims about when he died, the most prominent one is 1320 with others claiming it was in 1362 (Tatc1, 2013). His collection of poems 
from The Divan have been dated back to 1307 and consist of 417 poems of which 138 were written in prosody and the rest in syllabic meter. His other work is the Risaletü'n Nushiyye, or The Book of Advice, and also dates back to 1307. This work is one of the first examples of books on ethics in Anatolia and consists of 600 verses.

The content of his work comes from the Qur'an and hadiths, and excerpts of the worldviews of previous mystics such as Ahmed Yesevi, Haci Bektas, Rumi, İbn-i Arabi, Sadreddin Konevi, Abdulkerim Ciyli (Coşan, 1995); eastern mythologies (Tatc1, 2013); public stories; and daily events. According to Schimmel, the Yunus's phrases contain deep knowledge about Islamic tradition and reflect the deepest moods of religiosity (Schimmel, 1989 cited in Özçelik, 2014). In summary, all his poems can be said to be built up around a single axis, and his story is in fact the adventure of a person "on the way to his destination," (Gökcan Türkdoğan, 2011).

From the mystic perspective of Yunus Emre, Demirli (2009), who is known for his studies on Sadrettin Konevi and Ibn-i Arabi, mentioned that the poems of Yunus Emre contain Ibn-i Arabi's concept of the "unity of existence" in hidden form and that the expression of this concept is frequently confused with the concept of "fenafillah." He also mentioned that it is hard to interpret the Sufism of Yunus Emre just by relying on his poems since none of his prose narrated his approach to Sufism. In addition, by considering his expressions from various prose in different dimensions, Yunus Emre's approach can be said to approximate very closely the unity of existence that sometimes he expressed himself from an esoteric dimension, from a point where existence has not yet been revealed, and other times he expressed himself from a prominent dimension that belongs to a final phase of existence. Those who are not knowledgeable about Sufism cannot differentiate between these expressions, confusing it with pantheism. One can see the differences in expressions related to these dimensions below:

I came long ago, before the sky and earth were created (Yunus Emre, 2015, p. 190)

Before Adam was created, before life was molded, before Satan was cursed,

The Ninth Heaven was a roof to me" (Yunus Emre, 2015, p. 12)

The Wheel of Fortune did not exist when our souls were already in existence,

We had already been friends when Azrael (Angel of Death) was a stranger" (Yunus Emre, 2015, p. 198)

The One that binds this charm, the one speaks it in all tongues;

The One that can not be contained by heavens and earth contained by this heart (Yunus Emre, 2015, p. 246) 
I have searched the Heavens and Earth again and again, and I found it inside of Man (Yunus Emre, 2015, p. 275)

You are the One who sees in my eyes and says in my words,

You are the One that creates me, from the beginning to the end (Yunus Emre, 2015, p. 13)

\section{What is the Human?}

As a result of Yunus Emre's understanding of existence, the question of "What exactly is the human?" inevitably appears. The answer to this question cannot be provided without grasping the Islamic Sufism which underlies Yunus Emre's understanding of the human being and likewise understanding general sources such as verses in the Qur'an and hadiths, how the mystic perspective is not confined to its literal meanings, and how it differs. As a result, it is necessary to focus on concepts about the definitions of human being which appear in the Qur'an and Sufism. There are words that refer to human beings in the Qur'an in different dimensions such as the Human, person, Man, Adam, and more that all point to the different dimensions of the language of Sufism.

The first of these words is El-Insan, (The Human), "El" meaning "The" in English. The prefix implies that what is truly meant by human is reflected in this concept; therefore the concept of El-Insan (The Human) is the truth of the human. This concept is explained through the Perfect Human Being, or Universal Man (İnsan-1 Kamil) in Sufi mysticism and is the structure of becoming the mirror of Allah, the twin of the Qur'an. Its first appearance is mentioned also as the "Truth of Muhammad," (Hakikat-i Muhammediye). This term of The Human was mentioned by Abdulkerim el-Cili as the meaning and features of the word "Universe" in his work called the Perfect Human Being, (El İnsan-i Kamil, 2010). What is meant here is not an individual or a creature with a body but the absolute potential that reveals all the attributes of Allah as a whole as well as all other things that have been created.

What is meant by Adam or the Son of Adam (humanity) is the being on Earth that has a biological side created from dust and a Soul where all the attributes of Allah have been revealed, thus existing as the caliph of Allah on earth. Adam was created in heaven, but through the test referred to with the forbidden tree, he fell to earthly life from divine life and then remembered the holy names within himself, realizing his divine nature again, able to ascend to heavenly life through repentance.

Another word that the Qur'an refers to as "ins" means a conscious being with a biological body and is mostly used together with the word "jinn" which means a conscious being with no biological or molecular body. 
In Yunus Emre's poems, different kinds of narrations can be found that have addressed all layers of the human, from the nonphysical, abstract potential of "The Human" (El Insan) to mankind (ins) who is troubled by the ego. An expression from the first revealed levels of existence can sound meaningless and distant to many people, but expressions that originate from a lower or physical dimension more relevantly define people and concretely explain to them what should be done.

"I thought I was different, separated from the Friend (dost)

What has thrown me into this dream was the quality of the human."

"The appearance of Hakk, the inner truth is human, Hakk is within man, look out!

The whole world has already been amazed by the quality of the human."

"Whoever knows that Human may be a human, even he is a beast

Man is the sultan of every creation

Only oneness (tawhid) appears in everything indeed, Adam is the one who knows Oneness

The one who denies this oneness is hostile to his Soul.” (Yunus Emre, 2015, p. 98)

Yunus advised not to search for the divine outside of the entirety of one's own existence, instead he recommended searching for this divinity, which he called "the Friend," in one's self and in everything one perceives. "The Friend" (dost) is a Persian term which should be thought of as "a friend and lover, as a companion and guide, as a believer and Creator, as s Taptuk Emre (Yunus's Mentor) and Mohammad," (Dilçin, 1995). According to Yunus Emre, the Human is not distinct from "the Friend". He explains that the Soul of the Human is nothing else but "the Friend" and this Soul under the name of Adam could only know the oneness and singularity of being. One who knows this reality should leave aside the beast in the self (as a biological creature that will die and disappear) and know and recognize the Soul and one's closeness to the Friend. Pointing out two very well-known verses should help explain this:

They announced that the lover has died,

The dead one is the beast, lovers do not die. (Yunus Emre, 2015, p. 89)

Acquiring knowledge means to know one's self.

If you do not know yourself, you are worse than beasts. (Yunus Emre, 2015, p. 202)

In this case, the real existence of the person is the Soul, called the "lover" in Sufism, which is attached to one's essence and is on the path that returns to this 
essence. The existence of this is in fact the existence of the Creator, so it is impossible to disappear; only the beast, the bodily covering in which this Soul is wrapped, dies. The task here is to know ourselves, our real existence, the undying Soul.

\section{Concept of Self or Ego}

When one combines the things explained by Yunus Emre with other disciplines, the construct detailed below can be reached. The first is the conceptualization of the "multi-layered person" already used by Turkish and international transpersonal authors (Merter, 2006, 2014; Wilber, 1993). Whether one says that "the Soul of the person is not distinct from the existence of the Creator" or that "The consciousness, will, and power that created everything has also created the human," the conclusion is that the Human Soul is a divine entity. This constitutes the holistic, universal side of human. When this essence first appeared, as described in Mevlana's Mesnevi or Abdulkerim El Cili's Insan-i Kamil (2010), it had passed through the stages of mineral (molecular structure), plant (the biological structure with no nervous system), and animal (the structure with a nervous system that can consciously process information), finally arriving at the point of human within this biological structure, specifically in the brain.

In other words, a person unites all the layers before them. In this case, it means that the spiritual, biological, psychological, and sociological layers of the person implicitly exist together. When one looks from the paradigm of Sufism, the divine is seen to appear in others and create them. In this case, the revealed structure is in fact the self-structuring of this same consciousness and power.

Within this multi-layered structure, a conflict appears between the ego and spiritual side of humans, which Yunus Emre defined with the word "Soul." The Sufi principle of "Whoever knows the self, knows their Lord" states that Truth of the ego and self is also holiness. However, ego is used in Islamic and Sufi tradition as the curtain between the person and Allah, the thing which orders one to do bad things. The question of "Why use the same word for both positive and negative meanings?" now comes to mind. In fact, the reason for this dilemma is the identification of the Soul with the consciousness of stages in which it finds itself, saying "This is me." Ego and self are named according to the level of consciousness within which it identifies. In other words, when the ego, whose essence is not separate from the Soul, opens its eyes in the dimension of the body, it thinks that it is the body, saying "I am body" and starts living in accordance with bodily wants. At this level, the ego and self are called the "inciting ego/self" (Nafs-i ammarah). This has been described as an animalistic ego as it identifies with bestial characteristics. So when a person asks one's self "What am I?" and the answer given is in the direction of the physical, external, bestial ego, then pluraltiy and separation are indispensable because the bodily dimension declares that everyone perceives themselves separately from one another. 
Within this context, the ego is considered as a negative concept. But if the ego is predisposed, then it can be purified and find a way to recognize itself, purifying from a different curtain at every level and entering more subtle levels of consciousness.

In the level of ego of self-blame (nafs-i lawwame), one abandons the idea of accepting one's self as a body and starts to consider the self as a creature with a spirit and afterlife; when the level of ego is inspired (nafs-i mulhima), one considers the self as a consciousness that is not separate from the One. The ego and self, which recognizes its real essence at this point, can succeed at not regressing into a bodily personality again; if it can remain at this point of truth, then Truth is opened up to it and settles in permanently. This is called "nafs-i mutmainne" which means "the peaceful self." In the next stages, the ego (self) settles more into the truth it has discovered for itself. There are other levels of ego beyond this, where the consciousness continues to discover and experience itself more deeply. As these concepts have often been mentioned within Sufism literature, they remain outside the scope of this study.

If one looks at the levels of the ego from a multidisciplinary perspective, the issue can be connected to disciplines such as neuroscience, development, learning conditions, and cultural anthropology. One should also keep in mind that only the levels of inciting and self-blame can be examined from this multidisciplinary perspective if pushed, mulhime and the stages of ego after these would be beyond the reach of the concepts and research tools of these disciplines.

Let's go back to the concept of self/ego and begin to examine the subject neuroscientifically. The starting point is that the neurological equipment of a newborn human is not yet finished. The development of the brain does not finish within the womb due to the danger of not being able to exit the mother, continuing for a couple of years more after birth (Corel, 1975). This means that the neurological infrastructure of the brain is completed under relational impacts. Even though a biological basis for situations such as impulses, feeding, sleeping, defecation, pleasure, and sense of self exists, this ground gains meaning and improves relationally under social impacts (Mitchell, 1988). When looked at psychoanalytically, the "skin-ego" as the pioneer of the self (Anzieu, 2008) relies on a feeling of periphery that develops from the mother's touch which distinguishes the infant's body from other bodies. After the creation of the first bodily precursor of self in this way, patterns related to satisfying the physical, biological, and emotional need to relate are neurobiologically processed in the conscious and unconscious layers of the mind (Beebe \& Lachmann, 2013). As a result, biological, social, and environmental impacts collide and affect each other, establishing and forming the human consciousness or self.

When considering the brain, which has been mentioned as the most complex structure in the universe, as a platform where this self is revealed and created, our consciousness 
is known to have very little effect on the functions and processes of the brain. In other words, the brain executes its functions without the need of our ego, doing many things by itself without our awareness. The first chapter of the best-selling book by David Eagleman, Incognito (2011), explains the transactions our brain performs that we are not aware of; it is called "There is Someone In My Head But It's Not Me" and very similar to a sentence from Yunus Emre, "There is an I deeper in me than I," it is a very good example of how the neuroscientific point reaches closely to Sufism. Hood (2012) also argued that the brain creates the self as a result of interactions with other brains, that it is nothing more than narrations from the brain which facilitate experiences and interactions with the world. According to this point of view, the ego is an illusion of specific bundled memories, thoughts, and emotional trails; it is an illusion in the end.

To summarize the subject from the perspective of mysticism, the self is an imaginary construct created by the brain to observe itself and its world. When all of these things are brought together, one can reach the conclusion that the thing almost all people call "I" is the collection of identities established through the accumulation of memories as a result of interactions between biology and contexts of a relational, social, and cultural nature. One can say that humans live with a "formed self" in daily life, and this identity is the one that says "I." So when someone says "I," they define themselves through their values; the definitions of family, society, and culture in which they were born; and through their experiences in them. They could be someone's son, daughter, father, mother, husband, or wife. They could do a particular job and identify their self through the labels, expectations, and responsibilities of these roles. Their memory could be filled with all of these identifications, acceptances, and identities, their self could be defined through these memories. To use religious terminology, they have established a world and an identity from useless data that will lose all meaning in death.

Alongside this illusion and temporality, the self also inevitably encounters the "givens of existence:" death, isolation, meaninglessness, and freedom (Yalom, 1980). Even when one is in their happiest moment, they know that it is temporary and try to refrain from losing what they have. They realize that there is a gap between the self and those they are closest to. No matter what one does, it is all futile; meaning needs to be reproduced again and again, and the responsibility and freedom to choose this belongs to the individual. As a result, people have bad memories, dispersions, fears, weaknesses, conflicts, and passions because of the givens of existence and life itself. It is not possible for one to reach full peace because of all these appropriations, desires, and fears because only Allah does not desire, fear, or have regrets and weaknesses. On the other hand, the created suffers from this and that is why existentialist psychotherapy does not promise happiness or goodness for people but aims for us to confront our existence and its givens, to live life with awareness (Van Deurzen \& Adams, 2011). 
Alongside this mortal, formed formed self, there is a divine aspect of the human, the Soul, which is neither formed nor does it have an end. This divine side is within us in our internalization, our essence. Indeed, it is our real essence. Our biological, individual, and social aspects establish the formed self which prevents us from experiencing our Soul. In other words, the formed self is a curtain to the Soul. The "perception of the existence of independent creatures" outside (kesret) already prevents a person from experiencing singularity and oneness, and the formed self of the person thickens this curtain. Although there is nothing else besides the Truth (Haqq), the formed self gives existence to itself, draws borders, and separates itself from the rest of being. Whenever it feels any intrusion within its borders, it becomes worried and aggressive, turning aside to be unable to learn from life because it lives its life concerned with the pattern of protection and aggression. The words of Yunus Emre in his ethics book called Risaletin Nushiyye describe this created self as a beast and the ego as a rebel which deserves to be executed by hanging (Yunus Emre, 2011). We can think that there is a hidden dispatch here because being rebellious to The Compassionate One (Rahman) is a feature of the devil. The Qur'an says the "devil has rebelled against the Compassionate One," (Miriam Surah). The ego is just like this; what makes the person revolt against the Creator is this created, speculative self, the ego of the person. The solution is for the individual to quit identifying with their human identity and arguments, and realize that they are not separate from the Creator, the singularity, the plenary, or the whole, thus finding peace in holiness.

This means being able to look at existence and the self as a Friend, as the Creator. After this union is realized (visal), there is no need for the exchange between "you and me" (bazar), for the fear and struggle that comes from that. Yunus Emre tells all of the above in a few lines:

Being is the tent, but who would destroy this tent?

Only the brave one can lift the tent up from the face of the Friend.

Do not look around; you have become the tent of you,

Union is for the ones who neither think about before nor after

Leave your nafs (ego), look at the face of the Friend without your nafs. (Yunus Emre, 2015, p. 107)

\section{Human and Fear}

Yunus Emre related fear and the salvation from fear in finding or not finding the Truth within the self, not separating any one thing from another and thereby having nothing to fear. 
Since I have known myself, I have come closer and found the Truth (Haqq),

I was afraid until I found the Truth, now I am rid of those fears.

I do not think of separation from anyone, I do not fear, I favor not a single part

Who else shall I fear now? I have become lovers with whom I feared.

Azrael shall not come for my life. Questioning angels shall not come to my grave.

Why would they question me? I have become the One who makes them question. (Yunus Emre, 2015, p. 140)

There is nothing left to fear for the person who has digested the singularity and oneness in the way he mentioned because there is nothing left but the Truth (Haqq), and this never fears. Therefore, the person who discovers the Creator has nothing to lose and no threat to fear. As the human finds their self within the essence of Life which is holiness, they see life as an ongoing novel experience without fear. For them, everything that is experienced is a dream that happens upon the wish of Allah; they should be observed and lessons should be drawn from them.

For some people, this is perceived as a religious fiction and should not be accepted. If we consider that what someone does or does not believe is private, there can be different ways of explaining the same logic for these people. This difference can be explained in such a way as to express that as much as someone separates one's self from others, their own self will feel just as threatened.

While mentioning fear, the fear of death also needs to be mentioned in particular. The fear of death has different dimensions such as "fear of one's own death, fear of others' death, fear of the unknown after death, fear of being destroyed, and fear of dying slowly or in pain," (Akhtar, 2011; May \& Yalom, 1995; Yalom, 1980). According to Wilber (1991), the real thing that the modern person oppresses who has faced a wide range fear is not sex but death. Existentialist psychologists such as Yalom and May have stated that people face the fear of death at a very young age and develop several defense mechanisms to cope with this fear, such as the belief of an afterlife (May \& Yalom, 1995; Yalom, 1980).

For Yunus Emre, death is not something to be oppressed but something to be remembered over and over. In his poems, death occurs 332 times with different words and usages (Vural, 2011). As can be understood, there is a bipolar structure in such a usage of death. Firstly, death is described as a as a limit situation, as explained by Kaplan (1992) who was looking at it from an existentialist perspective using the concepts of Heidegger and Jaspers. Death as a as a limit situation is a scary experience that makes an individual realize their temporal existence within time. In this context, 
the statements below clearly reveal the coldness of death and how temporal we are when confronted with death. But this is valid only for our mortal, biological bodies.

The body decays within the ground, lying secretly in the grave,

I saw dissolved in blood-stained shrouds. (Yunus Emre, 2015, p. 171)

I see no choice about it, I have come to leave,

I am the warden of my goods, I have come to sell for the ones buying much. (Yunus Emre, 2015, p.142)

On the other hand, according to Islam and its spiritual Sufi side, the human does not die; we taste death. In Yunus Emre's words, "the beast (body) dies but the lovers do not. But being real lovers is only possible with the death of the bestial, speculative personality of the individual, born again as a lover." He connects this with the purification of our formed self to our own will before the biological death that takes us from this world. In other words, the death of all physical, bestial desire is the death of this formed, constructed personality and all its attachments and appropriations.

When death comes, it comes for bodies not souls. (Yunus Emre, 2015, p. 126)

We should die before we die not to die again. (Yunus Emre, 2015, p. 204)

If you have enough faith, live well in this world; if you could not finish here today, you also would not finish there tomorrow.

This is not an evaluation that ignores death, nor is it an attitude that is paralyzed or frozen by it. The death of personality is right there with all its bitterness, and the human who does this of their own free will before biological death strives to find their undying side. The point made here is that the Sufi neither denies physical death nor fears and runs from it; he sees death as a transformation and confronts it. The annihilation of self (fana) means the death of self with all its labels, appropriations, and values before the arrival of biological death.

\section{Love and the Relation between Mentor (Murshid) and Disciple (Murid)}

The fear of death and the fear of release from all bindings, ownership, and tags that feed the self is not something that can be passed individually. In order to achieve this, a love for Truth that surpasses all fears and someone or something to love are required. The important thing here is that the purification from all these fears and tensions is a process in itself, and it is necessary to have a guide who has already passed through this process.

In Sufism, the master who guides one into maturity is called the Murshid. The disciple who surrenders to a master, requesting to experience the Truth and be matured, is called the 
Murid. What will be mentioned here about the relation between mentor and disciple stems from the relation between Yunus Emre and his master, Taptuk Emre, and relies on the fact that the mentor has reached the Truth. In order to act as a guide and direct the person who has surrendered their self unto spiritual maturity and truth, the mentor must first experience this truth. In short, only the person who can swim can teach others how to swim. If there is a lack, then the figure who is assumed to be the mentor would lead people into a fantasy or construction that they have cultivated from what they've seen, listened to, and read. More negatively, the acceptance, culture, and narcissistic requirements of their self will interfere with this process; someone who has not yet experienced Truth cannot be a mentor, only a fellow, and it would be much better to refer to them as Ihvan (sibling) or Rafiq (companion).

When looking at the relation between mentor and disciple in Yunus Emre, one can see that this relation covers the function of guidance and a state of love where all purification and processes of remittance are performed voluntarily. The first subject to focus on is the concept of love. For Yunus Emre, the concept of love is very important:

Oh lovers, oh lovers, love is a religion to me, after my eyes saw the face of love,

the house of mourning is like a wedding day to me. (Yunus Emre, 2015, p. 8)

There is no man without love in this world. Everyone feels love for something, they are all lovers,

There are thousand types of likings in the world of Creator,

Which one of these do you deem yourself worthy for? (Yunus Emre, 2015, p. 68)

But this love is not the love for woman or man, or an erotic one; as Halman (2003) points out, we do not see the concept of sex in his poems. Then what is this love? For whom is it and why? The mystic love as stated here is the human attraction of returning to one's essence. If a person lacks this, Yunus Emre referred to that person as a biological creature, "a pasturing sheep" akin to one who is not aware of their Soul, their real essence. A kind of discontentment with daily life and search for Truth is what makes a person human. Underneath this he also talked about another attraction he called "sevgü" (liking), but the question he asked is very critical: "which one of these thousand types of likings do you deem yourself worthy for?" This is related to the individual's level of self-recognition, basically their level of consciousness, of ego, and of self. As a person is purified, the type and object of their love change. Anyone who does not feel their self-distanced from the Creator and Truth will only see and love the Creator and Truth. The person who defines their self only as a biological, social, and psychological self will only like people and things within that level.

At this point, it seems relevant to mention the function of romantic love in our lives. In daily life, this refers to love as mostly 
"romance" or "romantic love." Since this concept has entered into the life of modern Western people as a way of addressing certain feelings, imaginations, and ideals, people have begun chasing romantic love in order to give meaning to life (Mitchell, 2003). Johnson (1984) argued that the reason why people chase romance is basically due to the collapse of institutionalized religion in the West. Love is considered to be the only way remaining for people to escape from their little egoistic world. In other words, romantic love is the only means for people to feel transcendence.

For many people "giving meaning to life and the experience of leaving their own infertile life behind" is the real motivation being chased. If this is the real motivation, then the question of Yunus Emre "Which one of these thousand types of love do you deem yourself worthy for?" can possibly contain the question "How do you want to give meaning to your life?" So what happens in love then? It is obvious that the search for cognitive meaning is not the only thing that billions of people are running after.

Although the source of love comes from the transcendental nature of being human, love is manifested in the brain just like all other experiences. Therefore, before passing to mystic love, looking closer at the process of daily love as experienced in the brain could be a starting point for understanding the experience of spiritual love. Of course, the love of which Yunus Emre mentioned should be kept in mind in relation with the transcendental part of the human; it cannot be reduced to the biological dimension of the brain.

In the general experience described as love, hormones play an important role; oxytocin and vasopressin trigger the experience of attachment and with the excretion of dopamine, which is related to reward and attachment, love is turned into a rewarding experience (De Boer, Van Buel, \& Ter Horst, 2012; Zeki, 2007) Also, the regions related with negative feelings, social judgment, and evaluation of the intentions and feelings of others are deactivated; this explains why people in love do not care about critical evaluations or negative feelings towards them (Zeki, 2007). People ignore the social evaluations of others which normally control their behaviors and experience the ecstasy of love. Yunus Emre describes this situation as follows:

There is no mind, logic, drunkenness, nor wine for the ones who drink one sip from the goblet of love. (Yunus Emre, 2015, p. 23)

What Yunus Emre meant when he wrote "leaving honor aside" and "forgetting the pride of ego on the way of becoming a dervish" was that this state of passing and not caring about the judgment of others could only happen with the appearance of love.

At this point, to achieve this mentioned state of love as a real experience instead of an abstract construct or imaginary state requires being in love with a friend of the Creator. Yunus Emre described this as "being friends with the Friend who loves Friendship." This process necessitates purification. 
If you are a true lover, befriend the friend of the Friend,

You would be unfair to your Friend if you stay as you are. (Yunus Emre, 2015, p. 23)

I have lost myself, the Friend covered all of me. (Yunus Emre, 2015, p. 219)

In this relationship, one has to attach and surrender to a mentor who can reveal what the disciple could not yet reveal. Otherwise, an experience that is stated as loving Allah and loving the Creator will only stay in words and not transform into something that takes over the whole self.

As a reflection of this state of love, Yunus Emre mentioned his mentor, Tapduk Emre in 14 different places among his collected poems in the Divan. As it is not possible to share all of them, only two are mentioned below. When looking at these statements in general, Yunus Emre can be understood to have passed away from himself and disappeared in Tapduk Emre. He also stated that on Judgment Day, just as everyone will follow their own, he will again follow Tapduk.

When Raphael blows the last trumpet call, while everyone begs for their ego, I shall not mention Yunus, may Tapduk come to my lips at that moment" (Yunus Emre, 2015, p. 259)

Such a surrender of self has spiritual explanations that go beyond biological or psychological explanations. But one has to try and understand this phenomenon by pushing the frontiers of our knowledge. In order to help us understand this state of forgetting the self that is mentioned as love, one can consider some findings that have originated from the information processing of the nervous system in addition to the hormonal structure and anatomy of the brain which was mentioned above.

Csikszentmihalyi $(1990 ; 2014)$ observed that the information processing capacity of the nervous system has a limit, and therefore people who have left themselves to a creative task have their consciousness capacities filled with this creative flow, eventually forgetting themselves in the process. This experience of flow could provide an opportunity to explain the equivalent experience of Yunus Emre. Even if a person surrenders to someone else and completely concentrates on that other person to the point that they forget their own self, this "flow experience" will not allow any more room to process information pertaining to the self.

\section{The Problem of Narcissism and the Relationship between Mentor and Follower}

The realization of "forgetting the self" as mentioned above has become harder with every passing day due to the features of our age. Modern life defines people as common consumers with the limitless options of consumption it offers, imposing the need that we must have different characteristics to separate us from others; it 
inflates our ego through consumption. In this narcissistic era, people are absorbed with themselves and their needs (Twenge, 2014); we constantly reproduce and spread ourselves with the utilization of social media as well (Hood, 2012).

In order to escape from these narcissistic prisons, when we consider Csikszentmihalyi's "flow experience" and Frankl's (1985) explanations for finding meaning in life, the problem is seen as something that can be handled by focusing on something else, a creative process or a meaning. The common component of all these is the ability of a person to lean on other people or things apart from one's own self. The questions of how this can be realized or whether or not it can be taught are current subjects of psychology and ethics researchers, and more studies need to be conducted.

Yunus Emre used the concepts of enaniyet (ego), enne-ente (me and you), enteenne (you and I), nafs (self), kesret (plurality), teşrik (deeming anything as partner to Allah), and terk (renunciation) while mentioning this "you and I" dilemma (Dilçin, 1995) which narcissism is incapable of handling. However, Yunus can be seen to have solved the problem by using concepts such as unity of existence, unity, oneness, and transience of the world above personal and social contexts by looking from an ontological and spiritual perspective. His suggestions of "seeing the same Creator within one's self and others" and "realizing the world's temporal characteristic to leave aside the distinctions between you and me" can be cures for the problem of narcissism in contemporary society:

My soul was an eyeless soul, full of you and me. When I become a dervish,

I lose myself for this aim, my brother. (Yunus Emre, 2015, p. 325)

Now that Yûnus is you and me, there is no you and I for the lovers; loving someone requires nothingness, leave aside your divisive aspect. (Yunus Emre, 2015, p. 294)

Do not think that Truth (Haqq) is far away, Truth is inside your heart. Leave your ego,

Truth is within your soul beyond your body. (Yunus Emre, 2015, p. 44)

Ask Yunus of Tapduk, what did he understand of this life?

There is no subsistence in this world, neither for me nor for you! (Yunus Emre, 2015, p. 94)

Along with all these negative judgment about the self and narcissism, one can also see that the requirements of self and other narcissistic needs are natural and reasonable to a certain degree, and they have an important function within the process of mysticism. Kohut $(1971 ; 1977 ; 1984)$, an important theorist on narcissism, has pointed out that natural narcissistic needs are not harmful at all. According to him, narcissistic needs 
play an important role in the development of babies in terms of valuing one's self and gaining certain skills. The point where narcissistic needs turn into a problem is a result of insufficient satisfaction and a lack of optimal frustrations in the child. Thus an unrealistic search for omnipotence or praise from others continues even into adulthood.

A relationship with a wise mentor (murshid) who is idealized yet not considered as someone to compete with fulfills all kinds of narcissistic needs (Sayar, 2000). When looking from the perspective of Kohut in terms of conceptualizing narcissistic needs $(1971 ; 1977 ; 1984)$, the follower feels that they have been picked by the mentor for a special journey and can see that the mentor's divine potential (omnipotence) knows everything about them; they feel that the mentor provides them with whatever is needed, idealizing and establishing a special bond in an attempt to be like the mentor (twin situation). In this relationship, the expectations of a disciple are not always satisfied, and this frustration (optimal frustration) can lead to a life where they understand that neither they nor their needs are at the center of life; they are just a servant.

The relationship between the disciple and mentor goes beyond narcissistic interactions. First of all, the follower sees the mentor as the voice of the Creator, not just as a person. The mentor's function is to destroy the ego of the disciple. This aim goes beyond the goal of "bringing the narcissist requirements of a person to a healthy point," which is a main goal for a therapist of self-psychology. Therefore, the mentor implements such things as letting the person do embarrassing things, shaming the person by mentioning their faults in front of everyone, and so forth. Stories such as when Yunus Emre was sent to cut trees in the forest while everyone else listened to Taptuk Emre lecture in the dervish lodge, when Taptuk beat Yunus, and when he expelled Yunus are all examples. In many stories such as those from the Tezkiretül Evliya (Attar, 2007/1220), one can find further anti-narcissistic applications implemented by mentors on their followers.

Another aspect of this relationship that goes completely against the self is that the mentor, the one who gets others to reach maturity, is always active, while the disciple is always passive. Suspending the ego and letting the mentor be in control is required for a disciple to be rid of the chains that are the biological needs, social conditionings, and formed ego. The prototype for this can be seen in the relationship between Moses and Khidr which is explained in Surah Al-Kahf from the Qur'an. The duty of Moses is to follow Khidr no matter what he does without asking any questions. This is a complete method of incorporation without processing or filtering. When information that is received is incorporated through filtering or processing according to one's own opinion, this information becomes a product of the person's individual viewpoint and will not carry them beyond their current position. Worse than that, the information and experience is written as a record of ego resulting in a more inflated ego. In order to prevent this, the disciple's ego should in fact die. A Jungian 
analyst, Johnson (1984), has stated that the transition from one level of consciousness to another is akin to death for a person. Mitchell (1988) also argued that the patterns owned by a person become a part of the self, and leaving them aside makes the person feel insecure, as if they have lost their identity. In order to understand this experience it is important to be reminded of the term "dervish," which in Persian means "one that owns nothing, the poor," loosely referring to the general condition of Sufis. But the meaning of poor as used here is not someone without money but someone with no belongings or appropriations.

\section{Conclusion}

When all of these things are brought together and summarized, the mystic understanding of Yunus Emre presents an ontological point of view that gives meaning to existence and life. Within this perspective the origin of ego is based on Truth (Haqq), the real Soul. In this case, the human is not a biological creature who will die but the immortal Soul, the real lover on their way back to the origin. One's value does not come from one's individuality but from their divine and holistic feature.

In this case, human welfare is not found in nurturing, protecting, calming or praising the formed self or ego; instead, it is by realizing that they are not this formed ego and by directing one's self through purification to experience the Soul. This perspective completely opposes the current perspective in which modern psychotherapeutic applications and daily world struggles keep this formed self-alive and in need so as to feed the wrong self, the one that will eventually die. Even belief systems which consider the human as a biological body, as a formed self, try to moralize and make this formed self-transcendental and saintly; this is naught but an investment in a self that has never truly existed, that will eventually be destroyed. What really has to be done is to show the person that they are not just this body or formed self and to introduce them to their real existence and real essence, the Soul which originates from Truth (Haqq).

The only possible way that one can realize the transition from the illusory self to the holistic self is through love of Truth and a mentor or guide that has also experienced this love of Truth. The relationship that is established between mentor and disciple heals relational problems and has a nature that also frees humans from their biological, relational, societal, and psychological boundaries. One's moral sentiment based on this perception of life is oriented towards purifying the negative attributes that sustain the illusory self and towards gaining the virtues that will let one experience the real essence, the Soul. In this way, Yunus Emre has pointed out an understanding of existence; a meaning of life; and a remedial, liberating, and ethical relational model to those living in the age of narcissism. Just as we have been able to obtain so many results from the narrow scope of this research, conducting in-depth and comprehensive studies on Yunus Emre will also provide brand new horizons. 


\section{References}

Akhtar, S. (2011). Matters of life and death: Psychoanalytic reflections. London, UK: Karnac Books.

Anzieu, D. (2008). Deri-Ben (N. T. Demiryontan, Trans.) [Skin-Ego]. İstanbul, Turkey: Metis Yayınlar1.

Attar, F. (2007). Evliyat tezkireleri [Biographies of the Saints]. İstanbul, Turkey: Kabalc1. (Original work published 1220)

Beebe, B., \& Lachmann, F. M. (2013). Infant research and adult treatment: Co-constructing interactions. Routledge.

Corel, J. L. (1975). The postnatal development of the human cerebral cortex. Cambridge, MA: Harvard University Press.

Csikszentmihalyi, M. (1990). Flow: The psychology of optimal experience. New York, NY: Harper and Row.

Csikszentmihalyi, M. (2014). Flow and the foundations of positive psychology: The collected works of Mihaly Csikszentmihalyi. Dordrecht, Springer.

De Boer, A., Van Buel, E. M., \& Ter Horst, G. J. (2012). Love is more than just a kiss: A neurobiological perspective on love and affection. Neuroscience, 201, 114-124. Retrieved from http://www.sciencedirect.com/science/article/pii/S030645221101284X

Demirli, E. (2009). Yunus Emre'nin şiirlerinde vahdet-i vücud anlayışı [The notion of unity of existence in Yunus Emre's poems]. In I. Ulusal Yunus Emre Sempozyumu Bildiriler (pp. 317-330). Karaman, Turkey: Karaman Valiliği.

Dilçin, C. (1995). Yunus Emre'nin şiirlerinde 'ben-sen've 'benlik-senlik' kavramı [Concets of "I" - "you" and "I"ness - "you"ness in Yunus Emre's poems ]. In Uluslararasi Yunus Emre Sempozyuти Bildiriler Kitabı (pp. 385-398). Ankara, Turkey: Atatürk Kültür Merkezi Yayınları

Eagleman, D. (2011). Incognito: The secret lives of the brain. New York, NY: Pantheon.

El Cili, A. (2010) İnsan- Kamil (A. M. Torun, Trans.) İstanbul, Turkey: İz Yayıncılık.

Frankl, V. E. (1985). Man's search for meaning. Simon and Schuster.

Gökcan Türkdoğan, M. (2011). Yunus Emre'nin şiirlerinde “İnsan-1 Kamil” modeli [Perfect Man model in Yunus Emre's Poems]. In E. Boz. (Ed.), X. Uluslararasi Yunus Emre Sevgi Bilgi Şöleni Bildiriler Kitabı (pp. 347-367). Eskişehir, Turkey: Eskişehir Valiliği.

Halman, T. (2003). A'dan Z'ye Yunus Emre [Yunus Emre from A to Z]. İstanbul, Turkey: Yap1 Kredi Yayınları.

Hood, B. (2012). The self illusion: Why there is no 'you' inside your head. UK: Hachette.

Johnson, R. A. (1984). The psychology of romantic love. Routledge \& Kegan Paul.

Kaplan, M. (1992). Yunus Emre'ye göre zaman-hayat ve varoluşun manası [Meanings of time-life and existence according to Yunus Emre]. In Ulusal Yunus Emre Sempozyumu Bildiriler Kitabı (pp. 109-124). İstanbul, Turkey: Marmara Üniversitesi Yayınları.

Kohut, H. (1971). The Analysis of the Self. Connecticut, CT: International Universities Press.

Kohut, H. (1977). The restoration of the self. Connecticut, CT: International Universities Press.

Kohut, H. (1984). How does analysis cure. University of Chicago Press.

May, R., \& Yalom, I. (1995). Existential psychotherapy In R. Corsini \& D. Wedding, (Ed.), Current psychotherapies. (pp. 262-292). Illinois: F.E. Peacock Publishers.

Merter, M. (2006). Dokuz yüz katlı insan [Nine-thousand-layered Man]. Istanbul, Turkey: Kaknüs Yayınları 
Mitchell, S. A. (1988). Relational concepts in psychoanalysis. Cambridge, MA: Harvard University Press.

Mitchell, S. A. (2003). Can love last? The fate of romance over time. New York, NY: WW Norton \& Company.

Özçelik, M. (2014). Yunus Emre'nin dostları [Friends of Yunus Emre]. İstanbul, Turkey: Büyüyen Ay.

Sayar, K. (2000). Geçmişin bilgeliği bugünün psikoterapileriyle bulaşabilir mi? [Can the wisdom of past meet with today's psy] In K. Sayar (Ed.), Sufi psikolojisi [Sufi Psychology] (pp. 17-50). İstanbul, Turkey: İnsan Yayınları

Tatc1, M. (2013). Yunus Emre. Diyanet Vakfi İslâm ansiklopedisi içinde (pp. 600-606). İstanbul: Türkiye Diyanet Vakfi.

Twenge, J. M. (2014). Generation me-revised and updated: Why today's young Americans are more confident, assertive, entitled-and more miserable than ever before. Simon and Schuster.

Van Deurzen, E., \& Adams, M. (2010). Skills in existential counselling \& psychotherapy. London, UK: Sage.

Vural, H. (2011). Yunus Emre'de ölüm düşüncesi ve ölüme dair ifade sıklı̆̆ [Idea of death and frequency of expressions regarding death in Yunus Emre]. In E. Boz (Ed.), $X$. Uluslararası Yunus Emre Sevgi Bilgi Şöleni Bildiriler Kitabı (pp. 909-919). Eskişehir, Turkey: Eskişehir Valiliği.

Wilber, K. (1991). Grace and grit: Spirituality and healing in the life and death of Treya Killam Wilber. Boston, MA: Shambhala.

Wilber, K. (1993). The spectrum of consciousness. Illinois, IL: Quest Books.

Yalom, I. D. (1980). Existential psychotherapy. New York, NY: Basic Books.

Yunus Emre. (2011). Dîvân ve Risaletü'n-Nushiyye [Dîvân and Risaletü’n-Nushiyye] (Ed., M. Tatçı). İstanbul, Turkey: H Yayınları. (Original work published in an unknown date)

Yunus Emre. (2015). Dîvân (Ed., M. Tatçı). Ankara, Turkey: T.C. Kültür ve Turizm Bakanlığı. Retrieved from http://ekitap.kulturturizm.gov.tr/Eklenti/10663,metinpdf.pdf?0

Zeki, S. (2007). The neurobiology of love. Federation of European Biochemical Societies letters, 581(14), 2575-2579. Retrieved from http:/www.sciencedirect.com/science/article/ pii/S0014579307004875 